\title{
Spatial variation of macroinvertebrate community structure and associated environmental conditions in a subtropical river system of southeastern China
}

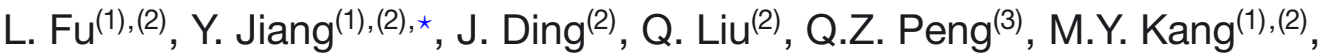 \\ L.Z. Wang ${ }^{(4)}$
}

Received December 20, 2014

Revised April 5, 2015

Accepted May 18, 2015

\section{ABSTRACT}

Key-words: $\quad$ Knowledge of macroinvertebrate distributions and associated environBiomonitoring, mental drivers in subtropical Asian rivers is relatively scarce. To fill this macroinvertebrate knowledge gap, we examined the spatial variation of macroinvertebrate communities, community structure and associated environmental conditions in a subspatial differentiation, tropical river system, the Dongjiang River Basin, in southeastern China. basin, indicators ings: (1) a distinct spatial differentiation of macroinvertebrate communities was present in the Dongjiang River Basin indicated by non-metric multidimensional scaling (NMDS), which corresponded to the northern region (NR), middle region (MR), and southern region (SR) gradient; (2) ANOVAs showed that diversity indices (total taxa, Margalef index and the Shannon diversity index), biotic indices (richness of EPT, percentage of EPT, and family biotic index) and most of the studied environmental conditions (elevation, slope, steam order, water temperature, electrical conductivity, dissolved oxygen, $\mathrm{pH}$, substrates, ammoniacal nitrogen, total phosphorus, percentage of urban land, percentage of rural land, and percentage of forest land) differed significantly among the three regions and a degradation gradient was observed in the NR-MR-SR direction; (3) Canonical correspondence analysis (CCA) revealed that NR sites were characterized by steep slope and coarse substrate, MR sites were characterized by high water temperatures and shallow slopes, and SR sites were primarily characterized by high total phosphorus and ammoniacal nitrogen concentrations; and (4) the Indicator Species Analysis, in conjunction with CCA analysis indicated that the most representative indicator taxon is Tipulidae for NR, Semisulcospira sp. for MR, and Branchiura sp. for SR.

(1) State Key Laboratory of Earth Surface Processes and Resource Ecology, Beijing Normal University, Beijing 100875, P.R. China

(2) College of Resources Science and Technology, Beijing Normal University, No. 19 Xinjiekouwai Street, Beijing 100875, P.R. China

(3) Faculty of Land Resource Engineering of KUST, Kunming University of Science and Technology, No. 68 Wenchang road, Kunming 650093, P.R. China

(4) International Joint Commission, PO Box 32869, Detroit, MI 48105, USA

* Corresponding author: jiangy@bnu.edu.cn 


\section{RÉSUMÉ}

La variation spatiale de la structure de la communauté des macroinvertébrés et les conditions environnementales associées dans un système fluvial subtropical du sud-est de la Chine

\section{Mots-clés :} biosurveillance, communautés

de

macro-

invertébrés, différenciation spatiale, bassin de la rivière Dongjiang, Indicateurs
La connaissance des distributions de macroinvertébrés et des facteurs environnementaux associés dans les rivières asiatiques subtropicales est relativement limitée. Pour combler cette lacune, nous avons examiné la variation spatiale de la structure de la communauté de macroinvertébrés et les conditions environnementales associées dans un système fluvial subtropical, le bassin de la rivière Dongjiang, dans le sud-est de la Chine. Au total 70 familles et 9 classes de macroinvertébrés ont été identifiées à partir de 74 sites échantillonnés en janvier 2013. Notre étude a tiré les conclusions suivantes : (1) une différenciation spatiale nette des communautés de macroinvertébrés dans le bassin de la rivière Dongjiang mise en évidence par «non-metric multidimensional scaling " (NMDS), ce qui correspond à un gradient de la région du nord (NR), à la zone médiane (MR), puis la région sud (SR); (2) des analyses de variance ont montré que les indices de diversité (total des taxons, indice de Margalef, de diversité de Shannon), les indices biotiques (richesse de l'EPT, pourcentage en EPT, et indice biotique), et la plupart des conditions environnementales étudiées (altitude, pente, ordre de Strahler, température de l'eau, conductivité, oxygène dissous, $\mathrm{pH}$, substrat, azote ammoniacal, phosphore total, pourcentage de terres urbaines, pourcentage de terres rurales, et pourcentage de terres forestières) différaient sensiblement entre les trois régions et un gradient de dégradation était observé dans le sens NR-MR-SR; (3) l'analyse canonique des correspondances (ACC) a révélé que les sites NR ont été caractérisés par la pente raide et un substrat grossier, les sites MR ont été caractérisés par des températures élevées de l'eau et des pentes faibles, et les sites de RS ont été principalement caractérisés par le phosphore total élevé et les concentrations d'azote ammoniacal; et (4) l'analyse des indicateurs spécifiques, en conjonction avec l'analyse CCA, a indiqué que le taxon indicateur le plus représentatif est Tipulidae pour NR, Semisulcospira sp. MR et Branchiura sp. pour SR.

\section{INTRODUCTION}

Biomonitoring is one of the most valuable tools for making management policies and practices for aquatic ecosystems (Barbour et al., 1996; Friberg et al., 2011). Macroinvertebrate assemblage measures are considered as effective and reliable indicators for environmental degradation and overall river health (e.g. Thorne and Williams, 1997; Smith et al., 1999; Bieger et al., 2010).

Relative to European and American river systems, subtropical Asian rivers support rich but poorly known macroinvertebrate communities (Morse et al., 2007). In addition, research on linkages between macroinvertebrates and their environment are lacking at the watershed scale in this region, resulting in poor river management practices, especially in China (Jiang et al., 2010). In many rivers, water is severely polluted as a result of untreated agricultural, urban, and industrial discharges with high concentrations of nutrients, organic materials, toxicants, and sediments (Pan et al., 2013). Several studies have suggested that nutrient pollutants (e.g. nitrogen and phosphorus) were dominant factors in determining macroinvertebrate assemblages compared with natural factors (e.g. water velocity and substrate size) in human-disturbed rivers (Chen et al., 2012; Liu et al., 2003; Pan et al., 2013). As a result, anthropogenic pollutants modify aquatic community composition from natural to tolerant dominated assemblages (Xu et al., 2013). Previous studies also showed that macroinvertebrate assemblages were affected by elevation (Chessman, 2006; Loayza-Muro et al., 2013), water temperature (Brown and May, 2000), conductivity (Miserendino et al., 2001; Stenert et al., 2008), fow velocity (Boyero and Bailey, 2001; Beauger et al., 2006), dissolved oxygen (Gabriels et al., 2007; Kaller and Kelso, 2007), substrates (Buss et al., 2004; Beauger et al., 2006), and 


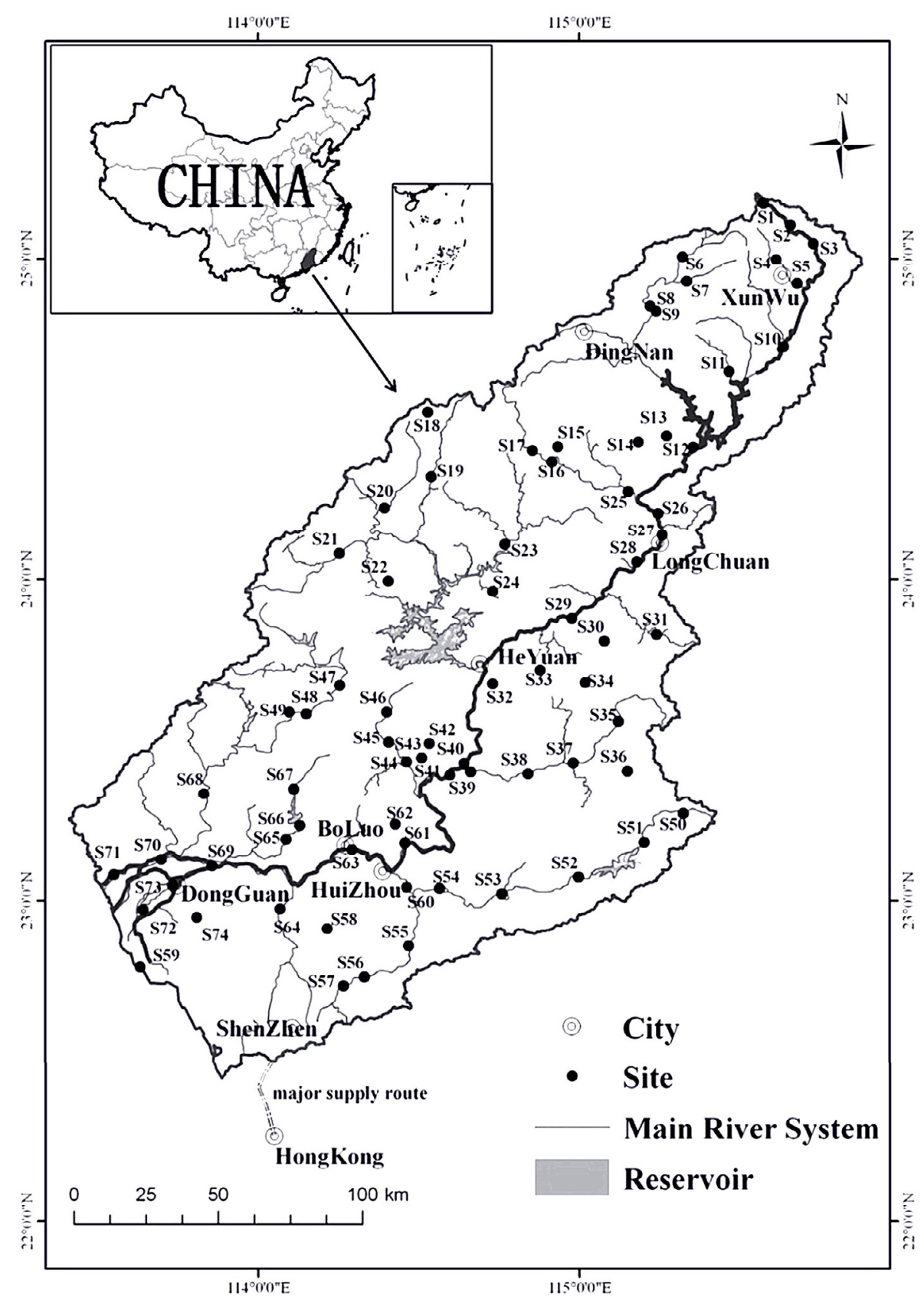

Figure 1

Map of the Dongjiang River Basin, showing the location of the study area and sampling sites (74 sites in total).

slope (Miserendino and Pizzolon, 2004; Roy et al., 2003). Therefore, a better understanding of macroinvertebrate communities in relation to environments is of great interest to river management (Bucker et al., 2010; Neff and Jackson, 2011).

The Dongjiang River is a major tributary of the Pearl River (the second largest river by discharge in China). It lies predominantly within the east-central part of Guangdong Province of southeast China (Zhang et al., 2008) (Figure 1). The lower Dongjiang River belongs to the Pearl River Delta region, where has been undergoing rapid economic development since the 1980s. Over the last few decades, this region has been transformed from predominantly fishing villages into urban centres. Land use has changed dramatically due to a variety of human activities, including agriculture, logging, sand extraction, industrial development, urban 
sewage discharges, and flow modification (Zhang et al., 2010). Rapid land development has increased the amount of anthropogenic disturbance to the river ecosystem and has damaged river health, including physical habitat alteration (Jiang et al., 2012; Zhou et al., 2012).

In the 1980s, a preliminary investigation of macroinvertebrates in Dongjiang River was conducted (Lai, 1988). More recently, some studies have explored the relationships between macroinvertebrates and substrate characteristics (Wang et al., 2007), land use (Zhang et al., 2010) and water quality (Li et al., 2013; Wang et al., 2011). However, knowledge in macroinvertebrate distribution and its associated governing factors at a basin-wide scale is still lacking due to the large area and the complexity of spatial variation. The studies mentioned above in this region are mainly focused at small scales (e.g., river main stem) or are based on a small number of samples, and do not reveal the broad-scale spatial differentiation and regulation of community structures across the entire basin. In addition, information on macroinvertebrate distributions and their governing environmental conditions is rarely reported at the level of the entire basin.

The objectives of this study were to (1) identify the large spatial differentiation in macroinvertebrate community structure across the entire Dongjiang River Basin, (2) examine how the distributions of macroinvertebrates are influenced by natural and anthropogenic factors, and (3) identify sensitive indicators that respond to spatial differentiation for future bioassessment.

\section{MATERIALS AND METHODS}

\section{> STUDY AREA}

The Dongjiang River Basin $\left(22^{\circ} 21^{\prime} \mathrm{N}-25^{\circ} 12^{\prime} \mathrm{N}, 113^{\circ} 04^{\prime} \mathrm{E}-115^{\circ} 50^{\prime} \mathrm{E}\right)$ encompasses an area of $35340 \mathrm{~km}^{2}$. It is the primary source of drinking water for Hong Kong and other regions of the Pearl River Delta in China (Ho et al., 2003). The main river channel is 562 km long, originating in the northeast of Jiangxi Province and extending to southwest of Guangdong Province with a decline in altitude, eventually discharging into the Pearl River estuary. The Dongjiang River basin is located in a subtropical climate region with a mean annual temperature of approximately $21^{\circ} \mathrm{C}$ and a mean annual precipitation of approximately $1900 \mathrm{~mm}$. Front- and typhoon-type rainfalls are predominant in the basin (Liu et al., 2010). The average annual discharge is 32.4 billion $\mathrm{m}^{3}$, of which $80 \%$ occurs during the wet season from April to October and $20 \%$ occurs between November and March (Lee et al., 2007). Forests cover the headwater mountain areas, and intensive cultivation dominates the other areas of hills and plains (Jiang et al., 2012). Large cities (e.g., Shenzhen, Dongguan, Huizhou, and Heyuan) with rapid development and growing economies are primarily located in the southern downstream areas of the basin (Figure 1).

\section{> MACROINVERTEBRATE SAMPLING AND LABORATORY PROCEDURES}

Fieldwork was carried out during the dry season in January 2013 during stable flow conditions. A total of 74 sites were sampled to represent all major habitat types across the entire basin (Figure 1). Quantitative macroinvertebrate samples were taken using multi-habitat sampling procedures (Lenat, 1988). At each sampling site (50-100 m reach, along the riverside), a single sample of macroinvertebrates was taken from one or more microhabitats: silt/sand, gravel/cobble, boulder, macroalgae/macrophyte, and marginal plant with three replicates. The number of habitat types sampled varied depending on their presence at each site. Silt/sand, macroalgae/macrophyte, and marginal plant habitats were sampled using D-frame nets $(0.3 \mathrm{~m}$, mesh size $500 \mu \mathrm{m})$ for a total channel length of approximately $3-5 \mathrm{~m}$ at water depth about $50 \mathrm{~cm}$ Gravel/cobble and boulder habitats were sampled using a Surber net sampler $(30 \mathrm{~cm} \times 30 \mathrm{~cm}$, mesh size: $500 \mu \mathrm{m})$ at water depth approximately $20 \mathrm{~cm}$. For all habitats of a site, the total composite sampling area was approximately $3 \mathrm{~m}^{2}$. The sampling gears were washed thoroughly between sites. The sampled materials were sieved through a 500-mm mesh sieve in the field for approximately 30-60 min. The specimens were manually 
separated from the sediment on a porcelain plate and preserved in $100-\mathrm{ml}$ plastic bottles containing $10 \%$ formaldehyde solution.

Where possible, macroinvertebrates were identified to the family (Crustacea, Insecta, Arachnida, Polychaeta, and Turbellaria) and genus (Gastropoda, Oligochaeta, Hirudinea, and Bivalvia) in the laboratory using identification keys (Liu et al., 1979; Morse et al. 1994; Thorp and Covich, 2001; Wang, 2002). Taxon identification to the family level has been reported adequate for providing a representative and persistent differentiation of macroinvertebrates distribution in response to pollution, land-use changes, and spatial differentiation (Bowman and Bailey, 1997; Chessman et al., 2007; Olsgard et al., 1998).

\section{> ENVIRONMENTAL CONDITIONS}

At each site, water samples were collected below the water surface prior to macroinvertebrate sampling for measuring the physical and chemical conditions. For nutrient analyses, water samples were transported to the laboratory at $4{ }^{\circ} \mathrm{C}$. The water temperature $\left(\mathrm{WT},{ }^{\circ} \mathrm{C}\right)$, electrical conductivity $\left(\mathrm{EC}, \mathrm{mS} \cdot \mathrm{cm}^{-1}\right)$, dissolved oxygen $\left(\mathrm{DO}, \mathrm{mg} \cdot \mathrm{L}^{-1}\right)$, and $\mathrm{pH}$ were measured using a portable YSI probe (YSI 6600) at the sites. The water velocity $\left(\mathrm{m}^{-1} \mathrm{~s}^{-1}\right)$ was measured near the river bed for 60 seconds using hydrometric propeller (LS1206B, Nanjing, China). Total nitrogen $\left(\mathrm{TN}, \mathrm{mg} \cdot \mathrm{L}^{-1}\right)$, ammoniacal nitrogen $\left(\mathrm{NH}_{3}-\mathrm{N}, \mathrm{mg} \cdot \mathrm{L}^{-1}\right)$, nitrate nitrogen $\left(\mathrm{NO}_{3}-\mathrm{N}, \mathrm{mg} \cdot \mathrm{L}^{-1}\right)$, and total phosphorus (TP, mg. $\mathrm{L}^{-1}$ ) were analysed using a UV spectrophotometer immediately upon the arrival of the samples at the laboratory.

The percentages of substrate types of each site were estimated based on the improved Wentworth scale. These types included sand/silt (diameter $0.1-2 \mathrm{~mm}$ ), gravel (2-16 mm), pebble (16-64 mm), cobble $(64-256 \mathrm{~mm})$, and boulder $(>256 \mathrm{~mm})$. Using the substrate data, the average substrate score (MSUBST), a quantization indicator of substrate constitution, was calculated (WFD-UKTAG 2008) as follows:

$$
\begin{aligned}
\text { MSUBST } & =\frac{-7.75 \times \text { BOLDCOBB }-3.25 \times \text { PEBBGRAV }+2 \times \text { SAND }+8 \times \text { SILTCLAY }}{\text { TOTSUB }} \\
\text { TOTSUB } & =\text { BOLDCOBB }+ \text { PEBBGRAV }+ \text { SAND }+ \text { SILTCLAY }
\end{aligned}
$$

where BOLDCOBB, PEBBGRAV, SAND, and SILTCLAY are percentage of bolder/cobble, pebble/gravel, sand, and silt/clay, respectively. A high score of MSUBST indicates a high proportion of sand and silt; conversely, a lower score indicates a high proportion of large rocks and cobble.

Percentages of forest agriculture, and urban land covers were calculated using Landsat 5 thematic mapper (TM) images taken in December 2009 at a spatial resolution of $30 \mathrm{~m}$. Land cover types were measured at a 1-km radius of the sampling site using ArcGIS 10 (Kong et al., 2013). The elevation $(\mathrm{m})$ of the sampling site was recorded with portable GPS (GARMIN ETR eTrex Venture). Channel slopes were determined using a 90-m-resolution digital altitude model (DEM; Shuttle Radar Topography Mission, SRTM). The stream Strahler order (Strahler, 1957) of a sampling site was determined using a river system map layer at a scale of 1:250 000 in ArcGIS 10.

\section{> DATA ANALYSIS}

Macroinvertebrate diversity indices, including total taxa (S), Margalef index (d; Margalef, 1957) and the Shannon diversity index $\left(H^{\prime}\right.$; Shannon, 1948), were calculated as follow:

$$
\begin{gathered}
d=(S-1) / \ln N \\
H^{\prime}=\sum_{s}^{i=1} p_{i} \ln p_{i}
\end{gathered}
$$

where $N$ represents the total number of individuals at a site; and $p_{i}$ represents the proportion of individuals found in the $i$ th taxon, with values summed across all taxa $(S)$. 
Number of Ephemeroptera, Plecoptera, and Trichoptera taxa (EPT-S) and percentage of Ephemeroptera, Plecoptera and Trichoptera individuals (\%EPT) for each site were calculated. Family biotic index (FBI; Hilsenhoff, 1988) was calculated as follow:

$$
F B I=\sum_{i}^{F} n_{i} t_{i} / N
$$

in which $F$ is the family number, $n_{i}$ is the number of individuals in the $i$ th family, $t_{i}$ is the tolerance value of the ith family, and $N$ is the sum of individuals. The tolerance values of macroinvertebrate families were from Hilsenhoff (1988) and Duan (2010).

To identify the spatial differentiation of macroinvertebrate assemblages, non-metric multidimensional scaling (NMDS) was performed with $\log (x+1)$ transformed abundance data (ind $\cdot \mathrm{m}^{-2}$ ). We used the Bray-Curtis similarity coefficient as the distance measure and computed the data with 250 maximum iterations, 40 real runs, and 50 randomized runs using the PC-ORD computer package (version 5.0; MjM Software, Gleneden Beach, Oregon, USA).

Bray-Curtis similarities analysis (ANOSIM; Clarke, 1993) was used to evaluate the degree of separation among the NMDS groups. Rank abundance data and presence/absence data were used in the analyses. High positive $R$ values (up to 1 ) indicated dissimilarity between groups. The number of Monte Carlo permutations was set to 9999. ANOSIM analyses were conducted using the PRIMER 5.0 software (Clarke and Warwick, 2001).

The Indicator Value method (IndVal; Dufrêne and Legendre, 1997) was used to identify the most representative macroinvertebrate taxa of each sampling site group using PC-ORD 5.0 program. IndVal is based on the relative frequency of taxa in the samples of one group and the mean abundance of taxa in the samples of that group relative to all groups. The indicator value (IV) varies from 0 to 100 , attaining its maximum value when all individuals belonged to one taxon for a group at all sites (Dufrêne and Legendre, 1997). The significance of the indicator values for each taxon was tested using Monte Carlo permutations (4999 permutations). One-way analysis of variance (ANOVA) and non-parametric rank-based one-way ANOVA (Kruskal-Wallis) analyses were used to test the significance of differences in the diversity indices, biotic indices, and environmental conditions among the site groups. The mean values of normally distributed datasets were analysed by one-way ANOVA. In cases when variance homogeneity (Levene's tests) was not achieved, the data were log $(x+1)$ transformed. The non-parametric Kruskal-Wallis test was applied if normality was not achieved after transformation. If significant differences were observed by ANOVA, post hoc pair-wise comparisons were performed using Tukey's test. All analyses were conducted using SPSS 19.0.

To assess the relationships between environmental conditions and the macroinvertebrate abundance (ind $\cdot \mathrm{m}^{-2}$ ), constrained ordination was used. Detrended correspondence analysis (DCA) was used to determine the appropriate type of model for direct gradient analysis. DCA indicated that the unimodal model (gradient lengths $>4$ standard units) would best fit the data, and hence Canonical Correspondence Analysis (CCA) was used. Prior to the analysis, macroinvertebrate data were transformed $\left(\log _{10}(x+1)\right)$. Taxa that occurred less than three sites and the relative abundance was less than $1 \%$ in a site were removed from the analysis to reduce the influence of rare taxa. Environmental variables were logarithmically transformed (except $\mathrm{pH}$ ) to approximate normality. CCA forward selection procedure was performed to select key environmental variables $(p<0.05$, Monte Carlo randomization test with 999 permutations). All analyses were conducted using CANOCO version 4.5 (ter Braak and Šmilauer, 2002). Exponential regression analyses were used to confirm the relationships between the sensitive taxa (abundance data) in each site group and their key influential variables.

\section{RESULTS}

\section{> MACROINVERTEBRATES COMPOSITION AND SPATIAL DIFFERENTIATION}

A total of 79 taxa of 9 classes were identified from 74 sampling sites (Appendix I), including Insecta (50 taxa), Gastropoda (13 taxa), Oligochaeta (4 taxa), Hirudinea (4 taxa), Lamellibranchia 

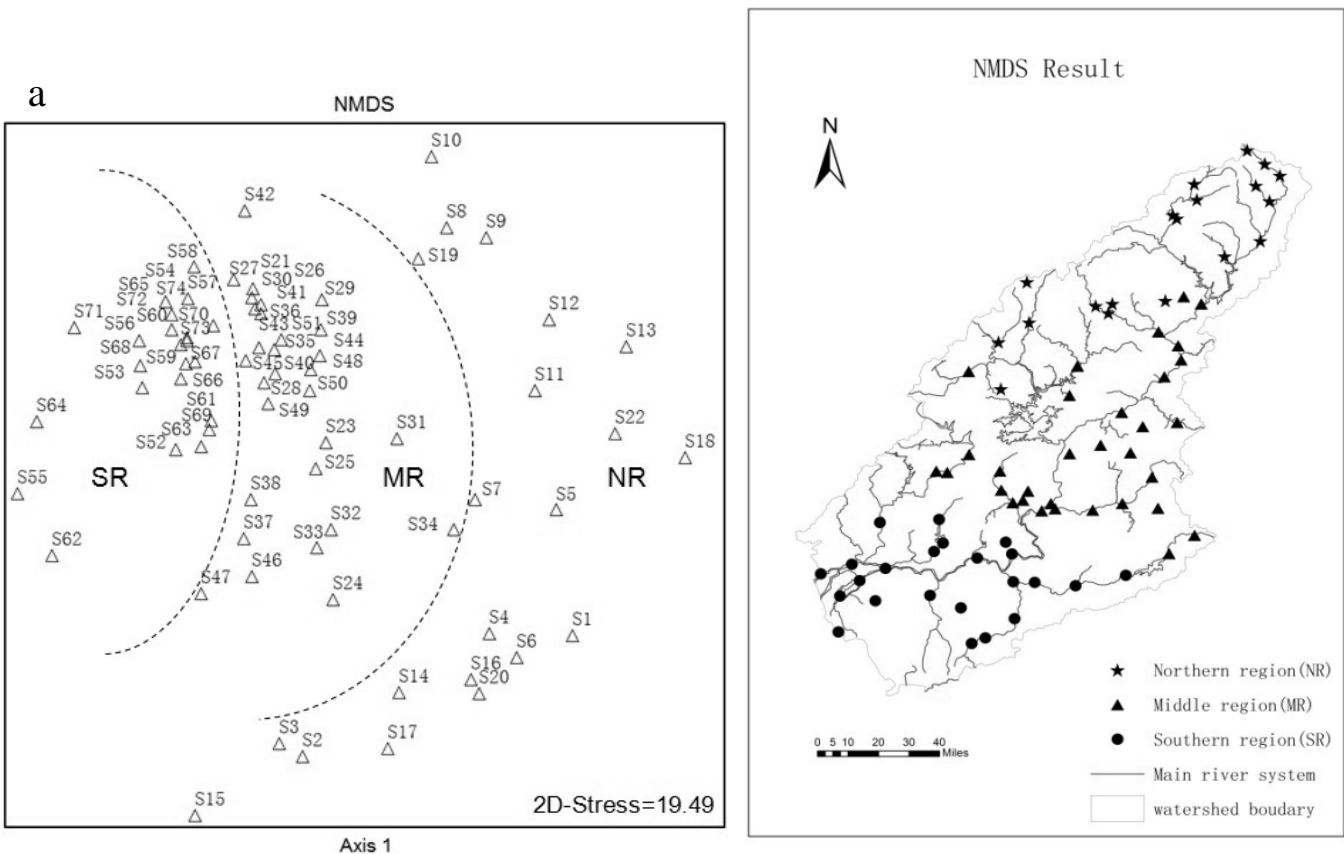

Ephemeridae $(r=0.566)$

Tipulidae $(r=0.554)$

Lestidae $(r=0.499)$

Hydropsychidae $(r=0.455)$

Pyralidae $(r=0.412)$

Branchiura sp. $(r=-0.433)$

Figure 2

(a) The ordination plot of macroinvertebrate communities in the Dongjiang River Basin obtained based on the NMDS method. The sites were divided into three groups corresponding to the southern region $(S R)$, the middle region (MR), and the northern region (NR). The stress value is 19.49, suggesting that the ordination is reliable but not an excellent interpretation. Taxa that are highly correlated $(r>0.4)$ with the first axis are listed below the plot; (b) Map showing the three regions identified by NMDS. Sites represented by asterisks belong to the northern region (NR), sites represented by triangles belong to the middle region (MR), and sites represented by circles belong to the southern region (SR).

(3 taxa), Crustacea (2 taxa), Arachnoidea (1 taxon), Turbellaria (1 taxon), and Polychaeta (1 taxon). Insecta accounted for $63.3 \%$, Gastropoda accounted for $16.5 \%$, and the remaining 7 classes accounted for $20.3 \%$ of the macroinvertebrate taxa.

With a final stress of 19.49 and instability of $<0.0001$, the two-dimensional solution in the NMDS ordination revealed spatial differentiation in macroinvertebrate assemblage structure. Two axes explained $79.1 \%$ of the variation (Axis $1=41.1 \%$; Axis $2=38.0 \%$ ). Three groups were clearly distinguished along the first axis gradient (Figure 2a). Considering their geographical locations, we found that the spatial distribution of macroinvertebrate communities exhibited strong regional differentiation (Figure 2b). The first group consisting of 21 sampling sites was located in the northwestern region (NR, sites represented by asterisks); the 2nd group consisting of 30 sampling sites was located in the middle region (MR, sites represented by triangles); and the third group consisted of 23 sampling sites was located in the southern region (SR, sites represented by circles). Accordingly, NMDS ordination revealed strong gradients associated with particular taxa. The first NMDS axis was highly correlated with the Ephemeridae $(r=0.566)$, Tipulidae $(r=0.554)$, Lestidae $(r=0.499)$, Hydropsychidae $(r=0.455)$ and Pyralidae $(r=0.412)$. These taxa were associated with mountain streams with 


\section{Table I}

Results of ANOSIM global and pair-wise comparisons among northern region (NR), middle region (MR), and southern region (SR) sites using rank abundance data and presence/absence data.

\begin{tabular}{|l|c|c|c|c|}
\hline \multirow{2}{*}{ Data type } & \multirow{2}{*}{ Global } & \multicolumn{3}{|c|}{ Pair-wise comparisons } \\
\cline { 3 - 5 } & \multirow{2}{*}{ Global $R$} & NR \& MR & MR \& SR & NR \& SR \\
\cline { 3 - 5 } & & $R$ & $R$ & $R$ \\
\hline Abundance & $0.107^{\star \star}$ & $0.084^{\star}$ & $0.091^{\star \star}$ & $0.176^{\star \star \star}$ \\
Pres/Abs & $0.11^{\star \star \star}$ & $0.085^{\star}$ & $0.094^{\star \star}$ & $0.193^{\star \star \star}$ \\
\hline
\end{tabular}

Significant $R$ values: ${ }^{\star} p<0.05 ;{ }^{\star \star} p<0.01 ;{ }^{\star \star \star} p<0.001$.

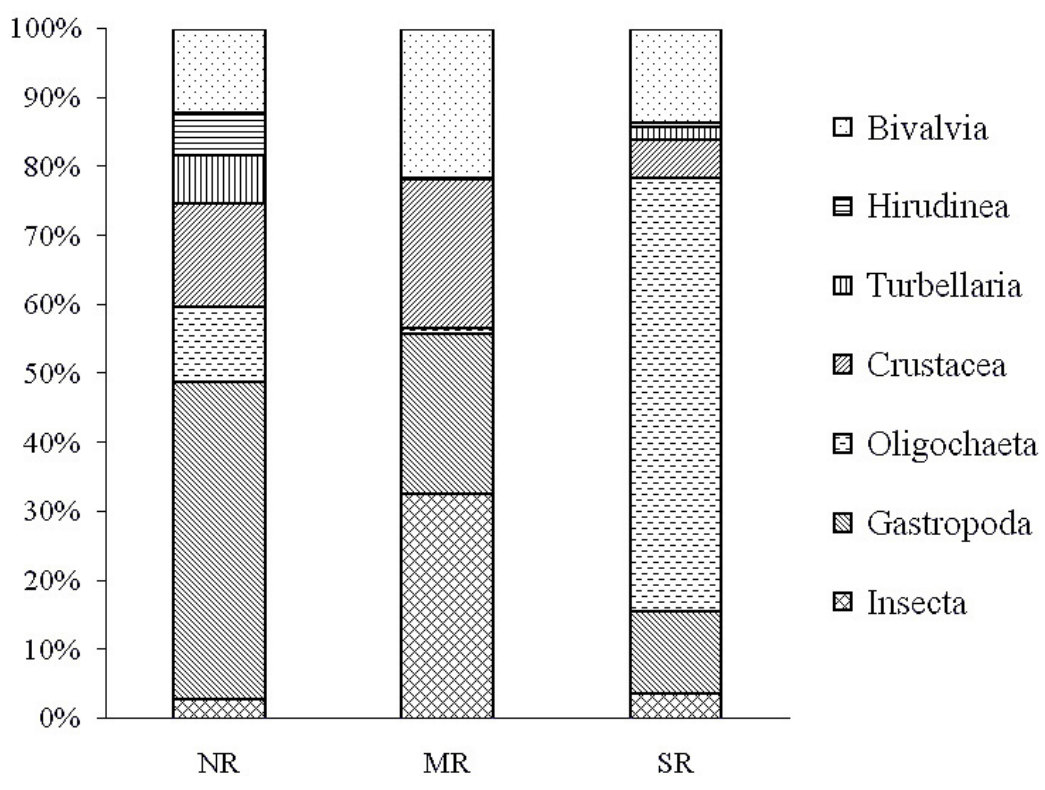

Figure 3

Stacked bar plots showing the percentage contributions of the macroinvertebrate compositions (abundance) for the northern region (NR), the middle region (MR), and the southern region (SR).

high dissolved oxygen concentrations, coarse substrates, and clean water. In contrast, the taxon Branchiura sp. was strongly negatively correlated with the first axis $(r=0.433)$ and was associated with habitats with low dissolved oxygen concentrations, fine substrates, and organic pollution. The second NMDS axis did not show clear associations between taxa and specific environmental variables.

The ANOSIM test showed significant differences in assemblage composition among the three site groups using both abundance data (Global $R=0.107, P<0.05$ ) and presence/absence (Global $R=0.11, P<0.001$ ) data (Table I). Pair-wise tests showed significant differences between regions $(p<0.05)$. The $R$-value obtained from the abundance data revealed that the difference between NR and SR $(R=0.176, p<0.001)$ was greater than that between MR and SR $(R=0.091, p<0.01)$ and that between NR and MR $(R=0.084, p<0.05)$. The same conclusion was drawn using the presence/absence data (Table I). These results indicate that the community similarity decreased with increasing geographic distance.

The NMDS and ANOSIM analyses characterized the macroinvertebrate assemblage composition of each site group. The total family-level taxa for NR, MR and SR were 56, 52 and 29; and the average abundances were 740,362 and 556 individuals $\cdot \mathrm{m}^{-2}$, respectively. The percentage contributions of different macroinvertebrate compositions (abundance data) of the three groups are shown in Figure 3. Gastropoda (46\%), Crustacea (15\%), and Bivalvia (12\%) had the highest percentage contributions to the assemblage composition in NR; and Insecta (33\%) and Gastropoda (23\%) made the greatest contributions to the assemblage composition in MR. Oligochaeta (63\%) was predominant phylum in SR, accounting for more than 


\section{Table II}

Indicator taxa and indicator values (IV) identified using IndVal analysis for northern region (NR), middle region $(M R)$, and southern region $(S R)$. Only taxa with $p<0.05$ were listed, which were identified using Monte Carlo permutation test (4999 runs).

\begin{tabular}{|l|c|c|c|c|c|}
\hline \multicolumn{2}{|c|}{ NR } & \multicolumn{2}{c|}{ MR } & \multicolumn{2}{c|}{ SR } \\
\hline Indicator taxa & V & Indicator taxa & IV & Indicator taxa & IV \\
\hline Radix sp. & 34.8 & Semisulcospira sp. & 23.8 & Branchiura sp. & 29.1 \\
Libellulidae & 33.3 & Haliplidae & 14.3 & Angulyagra sp. & 23.7 \\
Tanypodinae & 32.1 & Dytiscidae & 13.3 & Ampullariidae & 22.8 \\
Tipulidae & 30.3 & & & Tubifex sp. & 22.8 \\
Cipangopaludina sp. & 28.6 & & & & \\
Lestidae & 28.1 & & & & \\
Helobdella sp. & 27.9 & & & & \\
Calopterygidae & 22.8 & & & & \\
Hippeutis sp. & 21.8 & & & & \\
Ephemeridae & 21.8 & & & & \\
Glossiphonia sp. & 21.2 & & & & \\
Pyralidae & 19.0 & & & & \\
Leptophlebiidae & 14.3 & & & & \\
\hline
\end{tabular}

the sum of the remaining six phyla, and was much higher than in NR (11\%) and in MR (1\%). Arachnoidea and Polychaeta were excluded from the analysis because their low abundance $(<1 \%)$. The IndVal analysis identified 12 significant representative taxa for NR, 3 for MR, and 4 for SR (Table II). Two EPT taxa (Ephemeridae and Leptophlebiidae) were identified in the NR as clean water quality indicators, and 2 taxa of Tubificidae (Tubifex sp. and Branchiura sp.) were identified in the SR as organic pollution indicators.

\section{> DIFFERENCES IN INDICES AND ENVIRONMENTAL CONDITIONS AMONG REGIONS}

Macroinvertebrate diversities and biotic indices differed significantly $(p<0.05)$ among the three NMDS groups, and the mean values of the indices consistently ranked NR $>$ MR $>S R$ in water quality (Table III). Post hoc comparisons revealed that the mean value of $S$ (KruskalWallis, $H=18.939, p<0.001), H^{\prime}$ (Kruskal-Wallis, $H=14.176, p<0.01$ ), EPT-S (KruskalWallis, $H=10.178, p<0.01$ ), and EPT\% (Kruskal-Wallis, $H=8.071, p<0.05$ ) were the highest in NR, which were remarkably different from MR and SR. The $d$ showed significant differences (Kruskal-Wallis, $H=16.531, p<0.001$ ) among the three groups and mean value of each group decreased from NR to MR and to SR. The FBI score showed significant differences $\left(F_{2,71}=3.323, p<0.01\right)$ among the three groups and mean value of each group increased from NR to MR and to SR. In general, a degradation gradient of macroinvertebrate communities was observed in the NR-MR-SR direction.

All of the geographical and land-use conditions, as well as the majority of the water physicochemical conditions (WT, EC, DO, TP, $\mathrm{NH}_{3}-\mathrm{N}, \mathrm{pH}$ and MSUBST), differed significantly $(p<$ 0.05) among the three groups (Table III); however, TN (Kruskal-Wallis, $H=3.006, p>0.05$ ), $\mathrm{NO}_{3}-\mathrm{N}\left(F_{2,71}=0.722, p>0.05\right)$ and velocity $\left(F_{2,71}=0.685, p>0.05\right)$ showed no evidence of spatial differentiation. Post hoc comparisons showed that NR had a significantly higher percentage of forest land (Kruskal-Wallis, $H=35.602, p<0.001)$, elevation $\left(F_{2,71}=94.131\right.$, $p<0.001)$, slope $\left(F_{2,71}=25.559, p<0.001\right)$ and DO $\left(F_{2,71}=5.725, p<0.005\right)$ than the other regions, and had a significantly lower values of rural land $\left(F_{2,71}=5.284, p<0.01\right)$, urban land (Kruskal-Wallis, $H=39.762, p<0.001)$, MSUBST $\left(F_{2,71}=5.253, p<0.05\right)$, and WT $\left(F_{2,71}=16.252, p<0.001\right.$. In contrast, SR had a significantly higher values of urban land (Kruskal-Wallis, $H=39.762, p<0.001)$, stream order $\left(F_{2,71}=4.128, p<0.05\right)$, EC $\left(F_{2,71}=3.614, p<0.05\right)$, TP (Kruskal-Wallis, $\left.H=9.104, p<0.05\right)$, and $\mathrm{NH}_{3}-\mathrm{N}\left(F_{2,71}=4.229\right.$, $p<0.05$ ) than the other regions, but a significantly lower values of forest land (Kruskal-Wallis, $H=35.602, p<0.001)$, slope $\left(F_{2,71}=25.559, p<0.001\right)$, and $\mathrm{pH}\left(F_{2,71}=8.459, p<0.01\right)$. 


\section{Table III}

Means \pm SE for diversity indices, biotic indices, and environmental variables of each region. $n=$ number of sampling sites per region. An asterisk indicates $p<0.05$. The results of post hoc tests among the three regions are indicated by superscripts, and significant differences $(p<0.05)$ are indicated by different letters $(a, b, c)$.

\begin{tabular}{|c|c|c|c|c|c|c|c|}
\hline \multirow{2}{*}{ Variables } & \multirow{2}{*}{$\begin{array}{c}\text { NR } \\
(n=21)\end{array}$} & \multirow{2}{*}{$\begin{array}{c}\text { MR } \\
(n=30)\end{array}$} & \multirow{2}{*}{$\begin{array}{c}\text { SR } \\
(n=23)\end{array}$} & \multicolumn{2}{|c|}{ ANOVA } & \multicolumn{2}{|c|}{ Kruskal-Wallis } \\
\hline & & & & $F$ & $p$ & $H^{\prime}$ & $p$ \\
\hline \multicolumn{8}{|l|}{$\begin{array}{l}\text { Diversity and } \\
\text { biotic indices }\end{array}$} \\
\hline$s$ & $12 \pm 1^{\mathrm{a}}$ & $8 \pm 1^{b}$ & $5 \pm 1^{b}$ & & & 18.939 & $0.000^{*}$ \\
\hline$d$ & $2.46 \pm 0.20^{\mathrm{a}}$ & $1.65 \pm 0.24^{b}$ & $1.15 \pm 0.12^{c}$ & & & 16.531 & $0.000^{*}$ \\
\hline$H^{\prime}$ & $2.29 \pm 0.15^{\mathrm{a}}$ & $1.58 \pm 0.19^{b}$ & $1.28 \pm 0.14^{b}$ & & & 14.176 & $0.001 *$ \\
\hline EPT-S & $1.4 \pm 0.4^{\mathrm{a}}$ & $0.8 \pm 0.4^{\mathrm{b}}$ & $0.1 \pm 0.1^{\mathrm{b}}$ & & & 10.178 & $0.006^{*}$ \\
\hline EPT \% & $10 \pm 2.9^{a}$ & $5 \pm 2.1^{\mathrm{b}}$ & $2 \pm 1.2^{\mathrm{b}}$ & & & 8.071 & $0.018^{*}$ \\
\hline FBI & $4.2 \pm 0.2^{\mathrm{a}}$ & $5.6 \pm 0.2^{b}$ & $6.4 \pm 0.2^{\mathrm{c}}$ & 3.323 & $0.002^{*}$ & & \\
\hline \multicolumn{8}{|l|}{$\begin{array}{l}\text { Environmental } \\
\text { variables }\end{array}$} \\
\hline Urban (\%) & $0.7 \pm 0.3^{a}$ & $2.8 \pm 0.8^{\mathrm{b}}$ & $24.8 \pm 4.2^{c}$ & & & 39.762 & $0.000^{*}$ \\
\hline Rural (\%) & $11.1 \pm 2.4^{\mathrm{a}}$ & $25.5 \pm 2.6^{b}$ & $25.8 \pm 3.7^{b}$ & 5.284 & $0.007^{*}$ & & \\
\hline Forest (\%) & $84.3 \pm 2.6^{\mathrm{a}}$ & $66.1 \pm 4.5^{\mathrm{b}}$ & $31.3 \pm 5.2^{c}$ & & & 35.602 & $0.000^{*}$ \\
\hline Stream order & $3 \pm 0.2^{a}$ & $4 \pm 0.3^{\mathrm{ab}}$ & $5 \pm 0.4^{b}$ & 4.128 & $0.020^{*}$ & & \\
\hline Elevation (m) & $243 \pm 13^{\mathrm{a}}$ & $78 \pm 9^{b}$ & $17 \pm 4^{c}$ & 94.131 & $0.000^{*}$ & & \\
\hline Slope $\left({ }^{\circ}\right)$ & $5.75 \pm 0.54^{\mathrm{a}}$ & $3.77 \pm 0.49^{b}$ & $1.51 \pm 0.18^{c}$ & 25.559 & $0.000^{*}$ & & \\
\hline WT $\left({ }^{\circ} \mathrm{C}\right)$ & $14.0 \pm 0.44^{\mathrm{a}}$ & $16.6 \pm 0.35^{b}$ & $17.1 \pm 0.39^{b}$ & 16.252 & $0.000^{*}$ & & \\
\hline $\mathrm{DO}\left(\mathrm{mg} \cdot \mathrm{L}^{-1}\right)$ & $9.0 \pm 0.34^{\mathrm{a}}$ & $7.9 \pm 0.30^{\mathrm{b}}$ & $7.1 \pm 0.48^{b}$ & 5.725 & $0.005^{*}$ & & \\
\hline TP $\left(\mathrm{mg} \cdot \mathrm{L}^{-1}\right)$ & $0.12 \pm 0.03^{\mathrm{ab}}$ & $0.09 \pm 0.02^{\mathrm{a}}$ & $0.23 \pm 0.07^{b}$ & & & 9.104 & $0.011^{*}$ \\
\hline $\mathrm{NH}_{3}-\mathrm{N}\left(\mathrm{mg} \cdot \mathrm{L}^{-1}\right)$ & $1.59 \pm 0.79^{\mathrm{a}}$ & $0.84 \pm 0.21^{a}$ & $4.54 \pm 1.72^{\mathrm{b}}$ & 4.229 & $0.018^{*}$ & & \\
\hline $\mathrm{EC}\left(\mathrm{mS} \cdot \mathrm{cm}^{-1}\right)$ & $0.07 \pm 0.01^{\mathrm{a}}$ & $0.08 \pm 0.01^{a}$ & $0.17 \pm 0.36^{b}$ & 3.614 & $0.032 *$ & & \\
\hline $\mathrm{pH}$ & $7.28 \pm 0.05^{\mathrm{a}}$ & $7.23 \pm 0.09^{a}$ & $6.87 \pm 0.06^{b}$ & 8.459 & $0.001 *$ & & \\
\hline MSUBST & $1.52 \pm 0.82^{\mathrm{a}}$ & $3.07 \pm 0.64^{b}$ & $3.74 \pm 0.72^{b}$ & 5.253 & $0.034 *$ & & \\
\hline TN (mg. L $\left.^{-1}\right)$ & $2.64 \pm 0.43$ & $2.07 \pm 0.28$ & $4.57 \pm 0.07$ & & & 3.006 & 0.222 \\
\hline $\mathrm{NO}_{3}-\mathrm{N}\left(\mathrm{mg} \cdot \mathrm{L}^{-1}\right)$ & $1.33 \pm 0.22$ & $1.02 \pm 0.13$ & $2.37 \pm 0.77$ & 0.722 & 0.489 & & \\
\hline Velocity $\left(\mathrm{m} \cdot \mathrm{s}^{-1}\right)$ & $0.26 \pm 0.03$ & $0.22 \pm 0.02$ & $0.20 \pm 0.05$ & 0.685 & 0.513 & & \\
\hline
\end{tabular}

\section{$>$ RELATIONSHIP BETWEEN MACROINVERTEBRATE COMMUNITIES AND ENVIRONMENTAL CONDITIONS}

The first two CCA axes explained $57.6 \%$ of the variation in macroinvertebrate abundance. The forward selection procedure with the Monte-Carlo permutation test $(p<0.05)$ retained eight explanatory variables $\left(\mathrm{NH}_{3}-\mathrm{N}, \mathrm{TP}, \mathrm{NO}_{3}-\mathrm{N}, \mathrm{pH}, \mathrm{WT}\right.$, substrate, urban-cover percentage, and slope) (Table IV). The first axis (eigenvalue 0.545 ) accounted for $34.5 \%$ of the speciesenvironment association. $\mathrm{NH}_{3}-\mathrm{N}(r=0.70)$ and $\mathrm{TP}(r=0.66)$ were the most important environmental variables related to water quality from the first axis. The second axis (eigenvalue 0.234$)$, mainly contributed by slope $(r=0.49)$ and WT $(r=-0.46)$, accounted for $23.1 \%$ of the macroinvertebrate-environment correlation, reflecting the basin's topographical features and climate conditions (Table IV).

CCA biplot of samples versus environmental factors (Figure 4a) showed three distinct site groups: (1) almost all NR sites were clustered within the second quadrant, characterized by steeper slopes and coarser substrates; (2) the MR sites were situated on the lower half of the plot, characterized by relatively high temperatures and gradual slopes; and (3) the SR sites were located in the right side of the plot, distinguished by high organic pollution indicators (TP, $\mathrm{NH}_{3}-\mathrm{N}, \mathrm{NO}_{3}-\mathrm{N}$ ) and high percentages of urban land. The CCA site grouping is consistent with the NMDS results.

The associations among sensitive macroinvertebrate taxa and key environmental factors (TP, $\mathrm{NH}_{3}-\mathrm{N}$, slope, and WT) were apparent in the CCA analysis (Figure 4b). The abundance of Tubifex sp., Limnodrilus sp., Branchiura sp., and Coenagrionidae that had the highest scores on the first axis were significantly, positively correlated with TP $\left(R^{2}=0.64 ; P<0.001\right)$ and 


\section{Table IV}

Summary statistics for the canonical correspondences analysis (CCA) relating macroinvertebrate abundance to environmental variables. The important variables in Axis 1 and Axis 2 are shown in bold.

\begin{tabular}{|l|c|c|c|c|}
\hline \multirow{2}{*}{ Variables } & \multicolumn{2}{|c|}{$\begin{array}{c}\text { Correlations with } \\
\text { canonical axes }\end{array}$} & \multicolumn{2}{c|}{$\begin{array}{c}\text { Forward selection } \\
\text { of variables }\end{array}$} \\
\cline { 2 - 5 } & Axis 1 & Axis 2 & F-ratio & -value \\
\hline $\mathrm{TP}$ & $\mathbf{0 . 6 6}$ & 0.26 & 2.063 & 0.012 \\
$\mathrm{NH}_{3}-\mathbf{N}$ & $\mathbf{0 . 7 0}$ & 0.20 & 3.792 & 0.002 \\
$\mathrm{Slope}$ & -0.43 & $\mathbf{0 . 4 9}$ & 2.724 & 0.002 \\
Water temperature & 0.28 & -0.46 & 1.957 & 0.006 \\
$\mathrm{NO}_{3}-\mathbf{N}$ & 0.58 & 0.21 & 1.977 & 0.002 \\
$\mathbf{p H}$ & -0.49 & 0.24 & 2.098 & 0.010 \\
Substrates & 0.18 & -0.40 & 1.538 & 0.024 \\
percentage of urban cover & 0.59 & -0.11 & 2.111 & 0.004 \\
Eigenvalues & 0.352 & 0.234 & & \\
Species-environment correlations & 0.848 & 0.792 & & \\
Cumulative percentage variance & & & & \\
of species-environment relation & 34.5 & 57.6 & & \\
\hline
\end{tabular}

$\mathrm{NH}_{3}-\mathrm{N}\left(R^{2}=0.63 ; P<0.001\right)$ (Figures $5 \mathrm{a}$ and $\left.5 \mathrm{~b}\right)$. The abundance of Semisulcospira sp., Limnoperna sp., Nais sp., and Angulyagra sp. showed a positive correlation with water temperature $\left(R^{2}=0.52 ; P<0.01\right)$ (Figure $5 \mathrm{c}$ ). The abundance of the Rhyacophilidae, Odontoceridae, Ephemeridae, Tipulidae, Leptophlebiidae, and Elmidae from NR were positively associated with slope $\left(R^{2}=0.28 ; P<0.001\right)$ (Figure $5 \mathrm{~d}$ ).

\section{DISCUSSION}

\section{> SPATIAL DIFFERENCES AND REGIONAL CHARACTERISTICS OF MACROINVERTEBRATE COMMUNITIES}

The characteristics of the macroinvertebrate communities were closely associated with geographical conditions, land cover, and anthropogenic disturbance of the three identified regions. NR is a mountain forest dominated region that has relatively low levels of anthropogenic disturbance and has retained its original natural habitat. These conditions likely have maintained the least disturbed macroinvertebrate communities, which is reflected by that the EPT taxa, such as members of the Ephemeridae, Hydropsychidae and Baetidae, were more abundant in this region than in the other regions. The majority sites in NR were predominated by cobble and boulder substrates, and taxon occurrence of macroinvertebrates was influenced primarily by substrate type (Beisel et al., 1998). Usually, aquatic insect larva, especially the taxa preferring sticking onto the stones (e.g. Ephemeroptera and Trichoptera), were abundant in coarse substrate (Buss et al., 2004) Furthermore, although the second NMDS axis did not show clear associations between taxa and specific environmental variables, we found an evident gradient change of MSUBST in the sites of NR along this axis (Figure 2a).

$\mathrm{MR}$ is a hill-dominated, transitional region where sand extraction for construction is widespread (Zhang et al., 2010). The high percentage of Insecta species recorded in MR (Figure 3) was due largely to the high abundance of Chironomidae, which reached a maximum of 2290 individuals $\mathrm{m}^{-2}$. We speculate that sand extraction might increase the growth of Chironomidae because most Chironomidae species prefer sand-bottom substrates (Michael and David, 1984; John, 2004). Moreover, Chironomidae larvae can recolonize quickly to dredging due to their high dispersal ability and fecundity (Vermonden et al., 2011).

$\mathrm{SR}$ is a plain-urbanized region, where human impacts have greatly altered aquatic ecosystems. The agriculture and urban land-use practices degraded water quality by exporting fine sediments, nutrients, and pesticides; changing river channel physical properties; and reducing riparian vegetation. All of these could impact macroinvertebrate community composition 

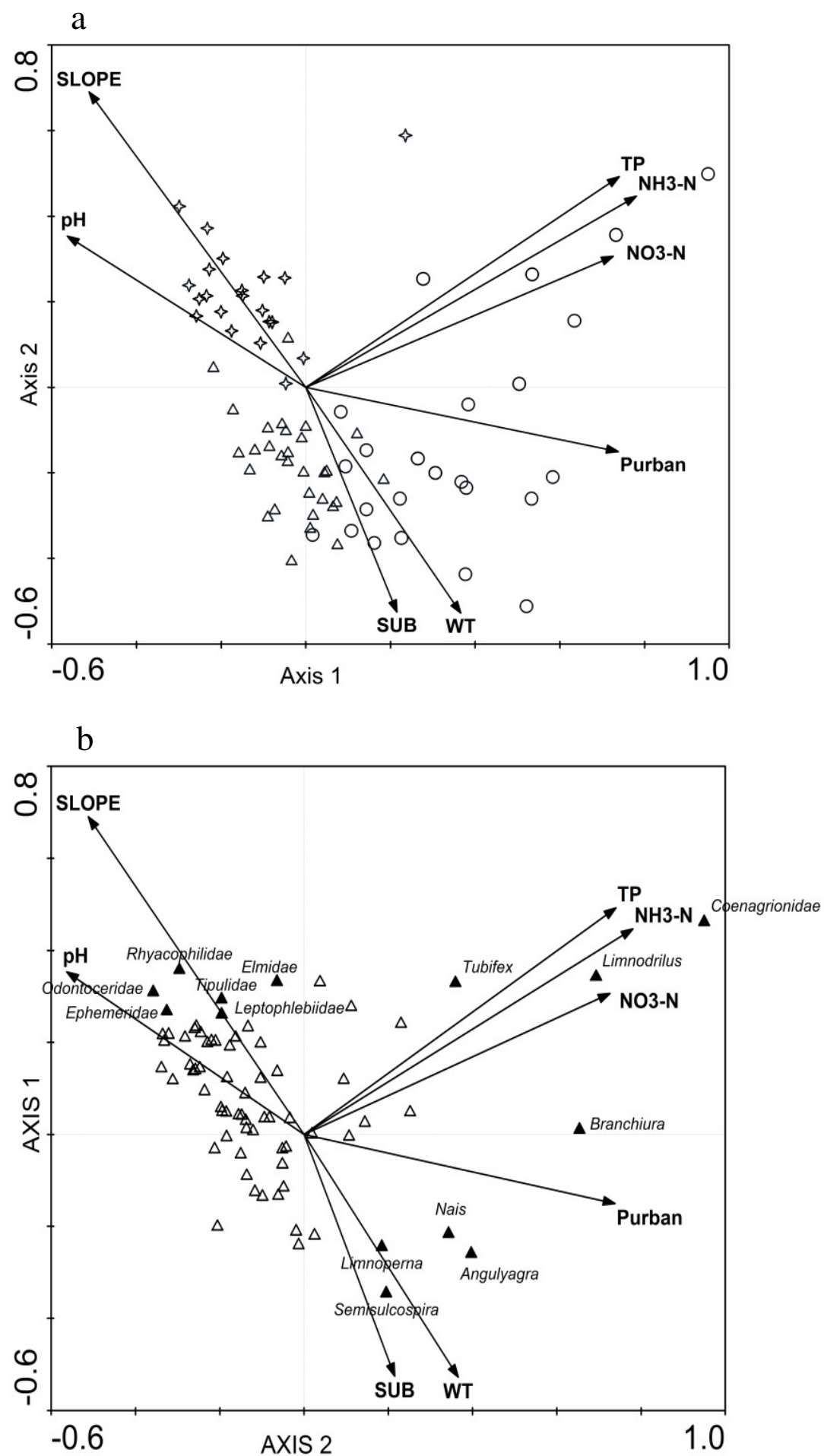

Figure 4

(a) Biplot of the CCA results of the sampling sites and environmental variables of the study area. The northern region (NR), the middle region (MR), and the southern region $(S R)$ sites are represented by asterisks, triangles, and circles, respectively. (b) Biplot of the CCA results for relations among macroinvertebrate taxa (abundance, triangles) and environmental variables (arrows). Taxa strongly associated with the environmental variables are indicated by solid triangles. Purban = percentage of urban; SUB = average substrate score; $W T=$ water temperature $\left({ }^{\circ} \mathrm{C}\right)$. 

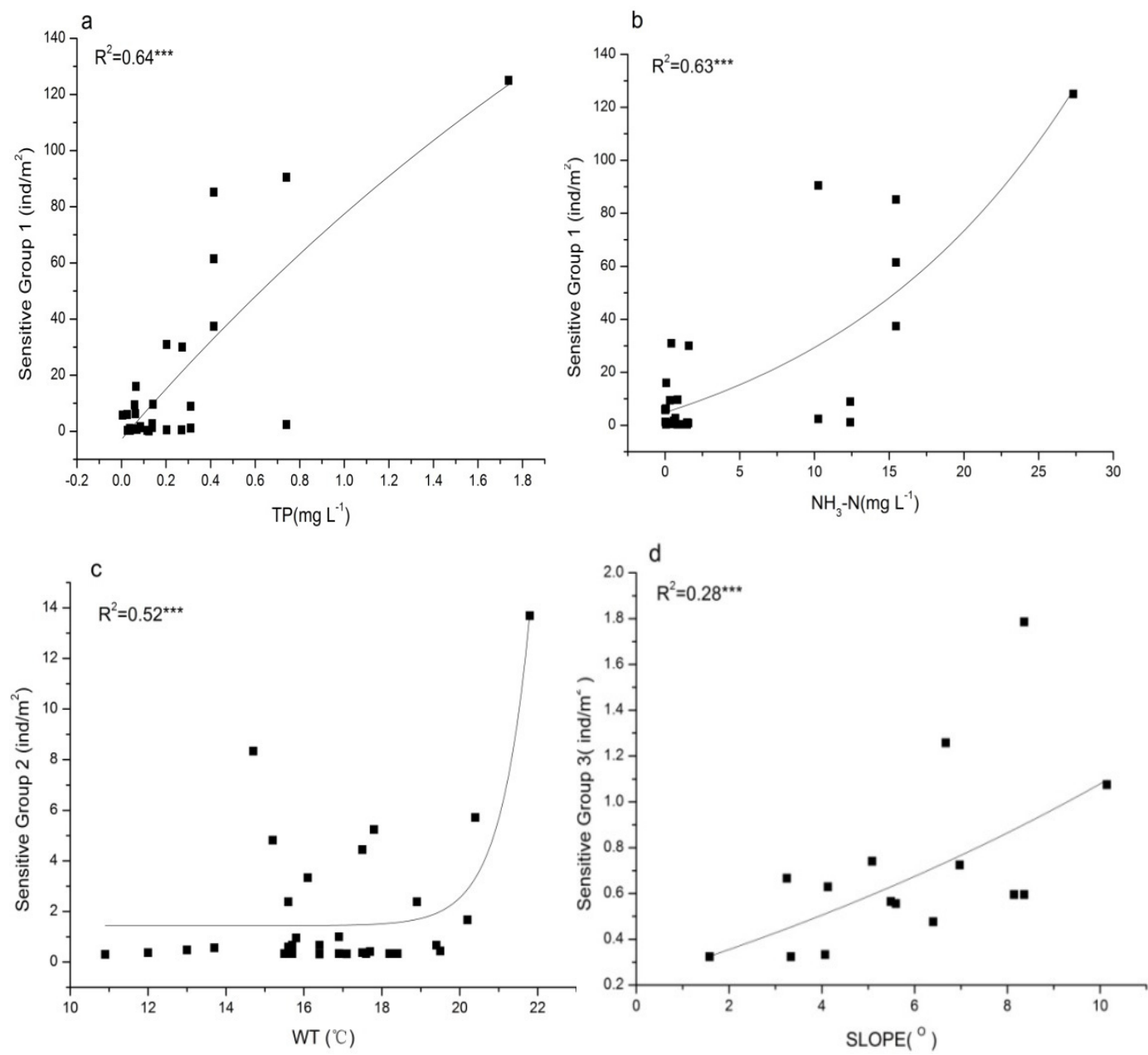

\section{Figure 5}

Relationships between the abundance of select taxa and key environmental variables. (a) Relationship between abundance of sensitive taxon group 1 (Tubifex sp., Limnodrilus sp., Branchiura sp., and Coenagrionidae) and concentration of TP; (b) Relationship between abundance of sensitive taxon group 1 and concentration of $\mathrm{NH}_{3}-\mathrm{N}$; (c) Relationship between abundance of sensitive taxon group 2 (Semisulcospira sp., Limnoperna sp., Nais sp., and Angulyagra sp.) and water temperature; (d) Relationship between abundance of sensitive taxon group 3 (Rhyacophilidae, Odontoceridae, Ephemeridae, Tipulidae, Leptophlebiidae, and Elmidae) and slope. Statistical significance: ${ }^{* *} p<0.001$.

(Paul and Meyer, 2001; Genito et al., 2002; Allan, 2004). The most abundant taxa were Tubifex sp. and Branchiura sp., and only 2 EPT taxa (Neoephemeridae and Baetidae) occurred in SR. These results suggest that the habitat and water quality conditions are much poorer in SR than in the other two regions. A survey by Gallacher (2001) indicated that domestic sewage was the most commonly listed problem facing this region, followed by agriculturally derived pollutions. The large amount of nutrient and sediment loads and other pollutants from such land uses jointly impact stream biological integrity by lowering water quality, degrading habitat, and interrupting ecosystem processes (Sponseller et al., 2001).

Using various analyses, we identified spatial distribution and regional differentiation of macroinvertebrate communities based on taxon data, diversity indices, biotic indices and their relations with environmental conditions. Our results are similar to those of Zhang et al. (2010) who showed that the macroinvertebrate community composition are distinctly different among the upper (4 sites), middle (4 sites) and lower (3 sites) sections of the Dongjiang River Basin. Similar distribution differentiation was also observed for the Lijiang River in southwestern China (Chen et al., 2012) and for the Taizi River in northeastern China (Qu et al., 2013). 
Our CCA results indicated that chemical conditions $\left(\mathrm{NH}_{3}-\mathrm{N}\right.$ and TP) and, to a lesser extent, physical properties (slope and WT) were the main environmental factors influencing macroinvertebrate distributions in the Dongjiang River Basin. These results suggest that nitrogen and phosphorus pollutants from human activity have greater effects on macroinvertebrate communities than natural factors. Nitrogen and phosphorus have been previously shown to be important in determining macroinvertebrates distributions and have been used to indicate the level of organic pollution of rivers (Maul et al., 2004; McCormick et al., 2004; Meng et al., 2009). Some studies in Asia, such as in Tamiraparani River in south India (Martin et al., 2000) and Juru River Basin in Malaysia (Al-Shami et al., 2011) reported that chemical parameters (e.g. $\mathrm{NH}_{3}-\mathrm{N}$ and TP) were main factors controlling the spatial heterogeneity of macroinvertebrate communities.

Inputs of phosphorus and nitrogen to freshwater systems not only compromise water quality but also deteriorate the diversity of aquatic fauna (Chambers et al., 2012). In the present study, as TP and $\mathrm{NH}_{3}-\mathrm{N}$ increased, the abundances of Tubifex sp., Limnodrilus sp., Branchiura sp. and Coenagrionidae increased pronouncedly (Figures $5 a$ and $5 b$ ). This nutrient-macroinvertebrate association is likely resulted from that the four taxa are tolerant species (with tolerance scores up to 9; Xu et al., 2013), have low dissolved oxygen requirements, and prefer organic-polluted habitats. The sites with high nitrogen and phosphorus concentrations were predominantly located within SR and associated with high percentages of urban land use (Figure 4a). With the local human population increase and economic growth, sewage output from industrial and residential sectors has rapidly increased, overwhelming municipal sewage disposal systems. Therefore, the harmful substances in sewage have directly or indirectly been released into the river system, causing eutrophication and pollution of the aquatic system.

In the present study, the concentration of $\mathrm{NH}_{3}-\mathrm{N}$ in many SR sites was above $1.00 \mathrm{mg} \cdot \mathrm{L}^{-1}$, at times exceeded $10.00 \mathrm{mg} \cdot \mathrm{L}^{-1}$ (Figure $5 \mathrm{~b}$ ). These concentrations exceed the freshwater aquatic life criteria for ammonia $\left(0.07-3.92 \mathrm{mg} \cdot \mathrm{L}^{-1}\right)$ in China (Yan et al., 2011). The sites (e.g., $\mathrm{S} 55, \mathrm{~S} 56, \mathrm{~S} 64, \mathrm{~S} 65)$ with the highest $\mathrm{NH}_{3}-\mathrm{N}$ concentrations $\left(>10.00 \mathrm{mg} \cdot \mathrm{L}^{-1}\right)$ are primarily located in industrial district cities (e.g., Shenzhen and Dongguan), and sewage outlets are the primary pollution sources. The macroinvertebrate diversity in these sites was very low, limited to several extremely tolerant taxa (e.g. Branchiura sp.). Hence, there is an urgent need to reduce the input of nitrogenous pollutants into freshwater system, especially in the southern urban area of the river basin.

\section{> POTENTIAL INDICATORS IN DIFFERENT REGIONS}

Relative to community-level statistical indices, such as total macroinvertebrate density, biomass, and richness, taxa-specific indicators generally provide a higher-resolution indication of the effects of anthropogenic disturbances (Johnson et al., 1992). Taxa-specific indicators of a region typically yield patterns with agglomerative distributions and are often associated with particular environmental conditions, especially conditions that closely reflect water quality and degree of pollution of the ecosystems.

Our IndVal method extracted "indicator taxa" for each region based on abundance and frequency (Table II) and those taxa represent the environmental condition where they occur (Figures $4 \mathrm{~b}$ and 5). Our results suggest that the Tipulidae, Ephemeridae, and Leptophlebiidae are suitable indicator taxa for NR, representing natural habitats with minimal human disturbance and clean water; Semisulcospira sp. are suitable indicator taxa for MR, preferring sandy substrates and relatively high water temperatures within a suitable range; and Branchiura sp. are useful indicator taxa for SR, indicating organic pollution and extensive habitat degradation.

Our results are consistent with those of Xu et al. (2013) who studied taxa-specific macroinvertebrate indicators from several sites in 14 rivers in China (including the Guanlan River in the 
Dongjiang River Basin) with varying pollution levels. They found that members of the Tipulidae, Ephemeridae, and Leptophlebiidae were indicators of good or very good water quality, Semisulcospira sp. were indicators of moderate or poor water quality, and Branchiura sp. were indicators of extremely poor water quality. Their results are consistent with the regional indicators of water quality identified for the three regions in our study.

\section{ACKNOWLEDGEMENTS}

The authors thank Professor Dayong Wu for his help with the specimen identifications. We are grateful to Bo Wang, Chenglong Tang, Kai Wu, and Tinghai Li for their help with the fieldwork. We also thank Prof. Han Y. H. Chen for reviewing this manuscript. This work was supported by the National Natural Science Foundation of China (41271104) and the National Science and Technology Major Project: Water Pollution Control and Management Technology of China (No. 2012ZX07501002-04).

\section{REFERENCES}

Allan J.D., 2004. Landscapes and riverscapes: the influence of land use on stream ecosystems. Annu. Rev. Ecol. Evol. Syst., 35, 257-284.

Al-Shami S.A., Md Rawi C.S., Ahmad A.H., Abdul Hamid S. and Mohd Nor S.A., 2011. Influence of agricultural, industrial, and anthropogenic stresses on the distribution and diversity of macroinvertebrates in Juru River Basin, Penang, Malaysia. Ecotoxicol. Environ. Safety, 74, 1195-1202.

Barbour M.T., Gerritsen J., Griffith G.E., Frydenborg R., McCarron E., White J.S. and Bastian M.L., 1996. A framework for biological criteria for Florida streams using benthic macroinvertebrates. J. N. Am. Benthol. Soc., 15, 185-211.

Beauger A., Lair N., Reyes-Marchant P. and Peiry J.L., 2006. The distribution of macro invertebrate assemblages in a reach of the River Allier (France), in relation to riverbed characteristics. Hydrobiologia, 571, 63-76.

Beisel J.N., Usseglio-Polatera P., Thomas S. and Moreteau J.C., 1998. Stream community structure in relation to spatial variation: the influence of mesohabitat characteristics. Hydrobiologia, 389, $73-88$

Bieger L., Carvalho A.B.P., Strieder M.N., Maltchik L. and Stenert C., 2010. Are the streams of the Sinos River basin of good water quality? Aquatic macroinvertebrates may answer the question. Braz. J. Biol., 70, 1207-1215.

Bowman M.F. and Bailey R.C., 1997. Does taxonomic resolution affect the multivariate description of the structure of freshwater benthic macroinvertebrate communities? Can. J. Fish. Aquat. Sci., 54, 1802-1807.

Boyero L. and Bailey R.C., 2001. Organization of macroinvertebrate communities at a hierarchy of spatial scales in a tropical stream. Hydrobiologia, 464, 219-225.

Brown L.R. and May J.T., 2000. Macroinvertebrate assemblages on woody debris and their relations with environmental variables in the lower Sacramento and San Joaquin River drainages, California. Environ. Monit. Assess., 64, 311-329.

Bucker A., Sondermann M., Frede H.G. and Breuer L., 2010. The influence of land-use on macroinvertebrate communities in montane tropical streams a case study from Ecuador. Fund. Appl. Limnol., 177, 267-282.

Buss D.F., Baptista D.F., Nessimian J.L. and Egler M., 2004. Substrate specificity, environmental degradation and disturbance structuring macroinvertebrate assemblages in neotropical streams. Hydrobiologia, 518, 179-188.

Chambers P.A., Mcgoldrick D.J., Brua R.B., Vis C., Culp J.M. and Benoy G.A., 2012. Development of environmental thresholds for nitrogen and phosphorus in streams. J. Environ. Qual., 41, 7-20.

Chen Q.W., Yang Q.R., Li R.N. and Ma J.F., 2012. Spring micro-distribution of macroinvertebrate in relation to hydro-environmental factors in the Lijiang River, China. J. Hydro-Environ. Res., 7, 103-112.

Chessman B., Williams S. and Besley C., 2007. Bioassessment of streams with macroinvertebrates: effect of sampled habitat and taxonomic resolution. J. N. Am. Benthol. Soc., 26, 546-565. 
Chessman B.C., Thurtell L.A. and Royal, M.J., 2006. Bioassessment in a harsh environment: a comparison of macroinvertebrate assemblages at reference and assessment sites in an Australian inland river system. Environ. Monit. Assess., 119, 303-330.

Clarke K.R. and Warwick R.M. (ed.), 2001. Change in Marine Communities: An Approach to Statistical Analysis and Interpretation. PRIMER-E Ltd., Plymouth, $172 \mathrm{p}$.

Duan X.H., Wang Z.Y. and Xu M.Z., 2010. Benthic Macroinvertebrate and Application in the Assessment of Stream Ecology, Tsinghua University Press, Beijing, 168 p. (in Chinese).

Dufrêne M. and Legendre P., 1997. Species assemblages and indicator species: the need for a flexible asymmetrical approach. Ecol. Monogr., 67, 345-366.

Friberg N., Bonada N., Bradley D.C., Dunbar M.J., Edwards F.K., Grey J. Richard B.H., Alan G.H., Nicolas L., Mark T. and Guy W., 2011. Biomonitoring of human impacts in freshwater ecosystems: the good, the bad and the ugly. Adv. Ecol. Res., 44, 1-68.

Gabriels W., Goethals P.L.M., Dedecker A.P., Lek S., De Pauw N., 2007. Analysis of macrobenthic communities in Flanders, Belgium, using a stepwise input variable selection procedure with artificial neural networks. Aquat. Ecol., 41, 427-441.

Gallacher D., 2001. The application of rapid bioassessment techniques based on benthic macroinvertebrates in East Asian rivers (a review). Int. Vereinigung Theoretische Angewandte Limnol. Verhandlungen, 27, 3503-3509.

Genito D., Gburek W.J. and Sharpley A.N., 2002. Response of stream macroinvertebrates to agricultural land cover in a small watershed. J. Freshwater Ecol., 17, 109-119.

Hilsenhoff W.L., 1988. Rapid field assessment of organic pollution with a family-level biotic index. J. N. Am. Benthol. Soc., 7, 65-68.

Ho K.C., Chow Y.L. and Yau J.T.S., 2003. Chemical and microbiological qualities of The East River (Dongjiang) water, with particular reference to drinking water supply in Hong Kong. Chemosphere, $52,1441-1450$.

Jiang X.M., Xiong J., Qiu J.W., Wu J.M., Wang J.W. and Xie Z.C., 2010. Structure of macroinvertebrate communities in relation to environmental variables in a subtropical Asian River system. Int. Rev. Hydrobiol., 95, 42-57.

Jiang Y., Ding Z.Y., Peng Q.Z., Liao J.Y. and Lv L.L., 2012. Spatial Distribution and Corresponding Factors of Heavy Metals Concentrations in the Dongjiang River Basin, Southeast China. Res. J. Environ. Earth. Sci., 4, 448-459.

John G.R., 2004. The colonization response of lotic chironomid larvae to substrate size and heterogeneity. Hydrobiologia, 524, 115-124.

Johnson R.K., Eriksson L. and Wiederholm T., 1992. Ordination of profundal zoobenthos along a trace metal pollution gradient in northern Sweden. Water Air Soil Pollut., 65, 339-351.

Kaller M.D. and Kelso W.E., 2007. Association of macroinvertebrate assemblages with dissolved oxygen concentration and wood surface area in selected subtropical streams of the southeastern USA. Aquat. Ecol., 41, 95-110.

Kong W.J., Meng W., Zhang Y., Gippel C. and Qu X.D., 2013. A freshwater ecoregion delineation approach based on freshwater macroinvertebrate community features and spatial environmenttal data in Taizi River Basin, northeastern China. Ecol. Res., 28, 581-592.

Lee J., Wang Z., Thoe W. and Cheng D., 2007. Integrated physical and ecological management of the East River. Water Sci. Technol., 7, 81-91.

Lenat D.R., 1988. Water quality assessment of streams using a qualitative collection method for benthic macroinvertebrates. J. N. Am. Benthol. Soc., 7, 222-233.

Li L., Yang Y., Min Q.Y. and Ran T., 2013. Macrobenthic community structure features and bioassessment of water quality in Dongjiang River. Ecol. Sci., 32, 313-317 (in Chinese with English abstract).

Lie Z.X., 1988. Investigation of macroinvertebrates in Dongjiang River. Freshwater Fisheries, 2, 28-34 (in Chinese).

Liu D.D., Chen X.H., Lian Y.Q. and Lou Z.H., 2010. Impacts of climate change and human activities on surface runoff in the Dongjiang River basin of China. Hydrol. Process, 24, 1487-1495.

Liu Y., Vermaat J.E., Ruyter E.D.de. and Kruigf H.A.M.de., 2003. The correlation between macrofauna distribution and nitrogen as well as phosphors in the pearl river and the Liuxi River. Acta Scientiarum Naturalium Universities Sunyatseni, 41, 95-99 (in Chinese with English abstract). 
Liu Y.Y., Zhang W.Z., Wang Y.X. and Wang E.Y., 1979. Economic Fauna of China: Freshwater Mollusca. Science Press, Beijing, 134 p. (in Chinese).

Loayza-Muro R.A., Duivenvoorden J.F., Kraak M.H. and Admiraal W., 2013. Metal leaching, acidity and altitude confine benthic macroinvertebrate community composition in Andean streams. Environ. Toxicol. Chem., 33, 404-411.

Margalef D.R., 1957. Information theory in Ecology. Gen. Systems, 3, 36-71.

Martin P.M. and Arunachalam M., 2000. Abundance and diversity of macroinvertebrates and fish in the Tamiraparani river, South India. Hydrobiologia, 430, 59-75.

Maul J., Farris J., Milam C., Cooper C., Testa S. and Feldman D., 2004. The influence of stream habitat and water quality on macroinvertebrate communities in degraded streams of northwest Mississippi. Hydrobiologia, 518, 79-94.

McCormick P.V., Shuford III R.B. and Rawlik P.S., 2004. Changes in macroinvertebrate community structure and function along a phosphorus gradient in the Florida Everglades. Hydrobiologia, 529, $113-132$.

Meng W., Zhang N., Zhang Y. and Zheng B.H., 2009. Integrated assessment of river health based on water quality, aquatic life and physical habitat. J. Environ. Sci., 21, 1017-1027.

Michael M.W. and David J.J., 1984. Associations among Chironomidae and sandy substrates in nearshore Lake Michigan. Can. J. Fisheries Aquat. Sci., 41, 174-179.

Miserendino M.L. and Masi C.I., 2010. The effects of land use on environmental features and functional organization of macroinvertebrate communities in Patagonian low order streams. Ecol. Indic., 10, 311-319.

Miserendino M.L. and Pizzolon L.A., 2004. Interactive effects of basin features and land-use change on macroinvertebrate communities of headwater streams in the Patagonian Andes. River Res. Appl., 20, 967-983.

Morse J.C., Yang L.F. and Tian L.X., 1994. Aquatic insects of China useful for monitoring water quality, Hohai University Press, Nanjing, 570 p.

Morse J.C., Bae Y.J., Munkhjargal G., Sangpradub N., Tanida K., Vshivkova T.S. Wang B.X., Li L.F. and Yule C.M., 2007. Freshwater biomonitoring with macroinvertebrates in East Asia. Front. Ecol. Environ., 5, 33-42.

Neff M.R. and Jackson D.A., 2011. Effects of broad-scale geological changes on patterns in macroinvertebrate assemblages. J. N. Am. Benthol. Soc., 30, 459-473.

Olsgard F., Somerfield P.J. and Carr M.R., 1998. Relationships between taxonomic resolution, macrobenthic community patterns and disturbance. Mar. Ecol. Prog. Ser., 172, 25-36.

Pan B.Z., Wang Z.Y., Li Z.W., Yu G.A., Xu M.Z., Zhao, N. and Gary B., 2013. An exploratory analysis of benthic macroinvertebrates as indicators of the ecological status of the Upper Yellow and Yangtze Rivers. J. Geogr. Sci., 23, 871-882.

Paul M.J. and Meyer J.L., 2001. Streams in the urban landscape. Annu. Rev. Ecol. Evol. Syst., 32, 333-365.

Qu X.D., Zhang Y., Ma S.Q., Zhao R. and Meng W., 2013. Spatial distribution characteristics of macroinvertebrate communities in Taizi River basin. Res. Environ. Sci., 26, 509-515 (in Chinese with English abstract).

Roy A., Rosemond A., Paul M., Leigh D. and Wallace J., 2003. Stream macroinvertebrate response to catchment urbanisation (Georgia, USA). Freshwater Biol., 48, 329-346.

Shannon C.E., 1948. A mathematical theory of communication. Bell System Technical Journal, 27, $379-423$.

Smith M., Kay W., Edward D., Papas P., Richardson K.S.J., Simpson J., Pinder A.M., Cale D.J., Horwitz P.H. J., Davis J.A., Yung F.H., Norris R.H. and Halse S.A., 1999. AusRivAS: using macroinvertebrates to assess ecological condition of rivers in Western Australia. Freshwater Biol. , 41, $269-282$.

Sponseller R.A., Benfield E.F. and Valett H.M., 2001. Relationships between land use, spatial scale and stream macroinvertebrate communities. Freshwater Biol., 46, 1409-1424.

Stenert C., Bacca R.C., Mostardeiro C.C. and Maltchik L., 2008. Environmental predictors of macroinvertebrate communities in coastal wetlands of southern Brazil. Mar. Freshwater Res., 59, 540-548.

Strahler A.N., 1957. Quantitative analysis of watershed geomorphology. Trans. Am. Geophys. Union, 38, 913-920. 
ter Braak C.J.F. and Šmilauer P., 2002. CANOCO, Reference Manual and CanoDraw for Windows User's Guide: Software for Canonical Community Ordination (Version 4.5). Microcomputer Power, Ithaca, New York, $500 \mathrm{p}$.

Thorne R. and Williams P., 1997. The response of benthic macroinvertebrates to pollution in developing countries: a multimetric system of bioassessment. Freshwater Biol., 37, 671-686.

Thorp J H and Covich A P. (ed.), 2001. Ecology and classification of North American freshwater invertebrates. Academic Press, New York, 1056 p.

Vermonden K., Brodersen K., Jacobsen D., van Kleef H., van der Velde G. and Leuven R., 2011. The influence of environmental factors and dredging on chironomid larval diversity in urban drainage systems in polders strongly influenced by seepage from large rivers. J .N. Am. Benthol. Soc., 30, 1074-1092.

Wang B., Liu Q.R., Zhou Y.L., Xiong X. and Jiang Y., 2011. The community structure of zoobenthos and bioassessment of water quality of the Dongjiang River. J. Hydro-Ecol., 5, 43-49 (in Chinese with English abstract).

Wang H.Z., 2002. Studies on taxonomy, distribution and ecology of microdrile Oligochaetes of China, with descriptions of two new species from the vicinity of the Great Wall Station of China, Antarctica. Higher Education Press, Beijing, 228 p. (in Chinese).

Wang Z.Y., Cheng D.S., Duan X.H. and Li X.W., 2007. Assessment of ecological system in East River and corresponding ecological restoration strategies. J. Hydraulic Engineering, 38, 1228-1235 (in Chinese with English abstract).

Water Framework Directive-United Kingdom Advisory Group (WFD-UKTAG)., 2008. River assessment methods benthic invertebrate fauna, river invertebrate classification tool (RICT). Doi: 978-1906934-07-1.

Xu M.Z., Wang Z.Y., Duan X.H. and Pan B.Z., 2013. Effects of pollution on macroinvertebrates and water quality bio-assessment. Hydrobiologia, 729, 247-259.

Yan Z.G., Meng W., Liu Z.T. and Yu R.Z., 2011. Development of freshwater aquatic life criteria for amonia in China. Environ. Sci., 32, 1564-1570 (in Chinese with English Abstract).

Zhang S., Lu X.X., Higgitt D.L., Chen C.T.A., Han J. and Sun H., 2008. Recent changes of water discharge and sediment load in the Zhujiang (Pearl River) Basin, China. Global Planet Change, 60, 365-380.

Zhang Y., Dudgeon D., Cheng D., Thoe W., Fok L., Wang, Z. and Lee J H.W., 2010. Impacts of land use and water quality on macroinvertebrate communities in the Pearl River drainage basin, China. Hydrobiologia, 652, 71-88.

Zhou T., Wu J.G. and Peng S.L., 2012. Assessing the effects of landscape pattern on river water quality at multiple scales: A case study of the Dongjiang River watershed, China. Ecol. Indic., 23, 166-175.

Cite this article as: L. Fu, Y. Jiang, J. Ding, Q. Liu, Q.Z. Peng, M.Y. Kang and L.Z. Wang, 2015. Spatial variation of macroinvertebrate community structure and associated environmental conditions in a subtropical river system of southeastern China. Knowl. Manag. Aquat. Ecosyst., 416, 17. 
Appendix I. List of macroinvertebrates in the study sites.

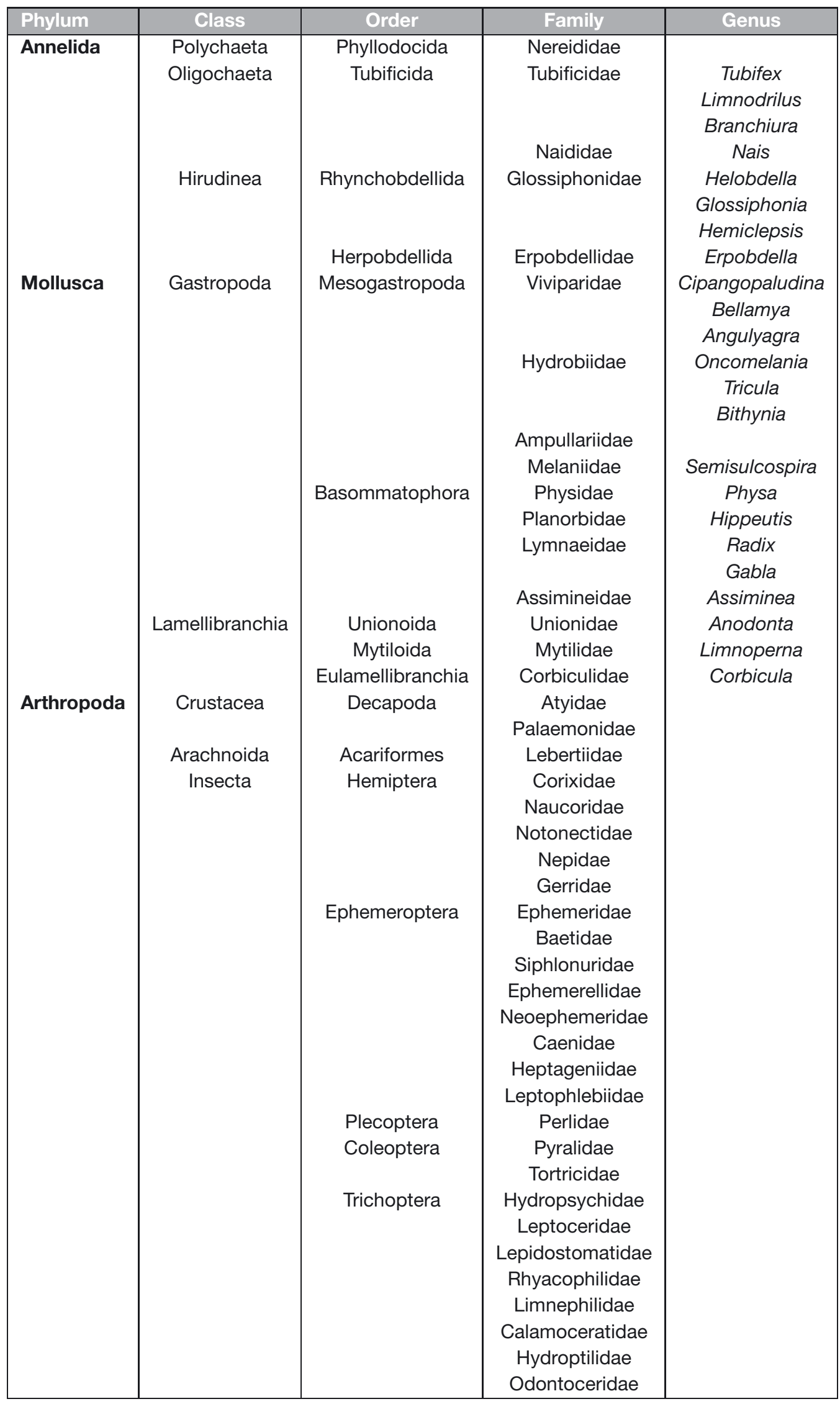


Appendix I. Continued.

\begin{tabular}{|c|c|c|c|c|}
\hline Phylum & Class & Order & Family & Genus \\
\hline Platyhelminthes & Turbellaria & $\begin{array}{c}\text { Megaloptera } \\
\text { Coleoptera } \\
\text { Odonata } \\
\text { Diptera }\end{array}$ & $\begin{array}{c}\text { Corydalidae } \\
\text { Elmidae } \\
\text { Haliplidae } \\
\text { Staphylinidae } \\
\text { Gyrinidae } \\
\text { Dytiscidae } \\
\text { Hydrophilidae } \\
\text { Hydraenidae } \\
\text { Gomphidae } \\
\text { Macromiidae } \\
\text { Corduliidae } \\
\text { Libellulidae } \\
\text { Calopterygidae } \\
\text { Coenagrionidae } \\
\text { Aeshnidae } \\
\text { Lestidae } \\
\text { Cordulegastridae } \\
\text { Tanypodinae } \\
\text { Orthocladiinae } \\
\text { Chironominae } \\
\text { Simuliidae } \\
\text { Dolichopodidae } \\
\text { Stratiomyidae } \\
\text { Tipulidae } \\
\text { Psychodidae } \\
\text { Tabanidae } \\
\text { Dugesiidae }\end{array}$ & \\
\hline
\end{tabular}

